\title{
Learning Model of Performing Arts of Dance Based on Conservation
}

\author{
Atip Nurharini, \\ Universitas Negeri Semarang, Indonesia \\ atip.nurharini@mail.unnes.ac.id \\ Eko Purwanti \\ Universitas Negeri Semarang, Indonesia \\ purwanti17@mail.unnes.ac.id
}

\author{
Yuyarti, \\ Universitas Negeri Semarang, Indonesia \\ yuyarti@mail.unnes.ac.id \\ Fakhruddin, \\ Universitas Negeri Semarang, Indonesia \\ fakhruddini@mail.unnes.ac.id
}

\begin{abstract}
This research aims to find out the learning process implementation of conservation-based dance performances and the forms of dance performances. To obtain data and information relating to the studied issues was conducted in various ways, namely through documentation, questionnaires, observations, and field notes. The methods used in the process of creating dance is including appreciation, imagination, exploration, creativity, composition, and concept formation, while the data analysis technique used was qualitative analysis with descriptive method. The results showed that: Implementation of performing arts of dance based on conservation can run well and student dance performance in conservation concept had a good result. The conclusion of the research is conservation and can be used as a learning model in performing art of dance for building creative, superior, competitive and characteristic student work.
\end{abstract}

Keywords: The learning model, conservation, dance performance, dance education

\section{INTRODUCTION}

Universitas Negeri Semarang (UNNES) as part of universities in Indonesia has an identity and culture by contributing positively and constructively to the progress of the nation. The positive and constructive contribution has been incarnated with success in setting up as a conservation campus. The meaning of conservation is protection, preservation, and sustainable use of natural resources, the environment, art and culture. To support the existence of conservation identity can be implemented by involving the citizens of Universitas Negeri Semarang who are obliged to preserve and use sustainably the flora and fauna located within Universitas Negeri Semarang and its surroundings. The purpose of these actions is to support the function of the environment and to create a beautiful and comfortable environment [13].

As residents of Universitas Negeri Semarang, lecturers and students must always work together to realize conservation identity in order to increase the existence, development and benefits for the University's progress. It means that every course at Universitas Negeri Semarang supports conservation program.

To prepare the quality of the lecture, it starts dance art learning with lecture activities involving lecturers and students who are active, creative, inspirational, and innovative. The data in the field showed that: lecturers lacked the understanding of the conservation meaning associated with the lecture material, and the conservation meaning had not been a habit for students in their campus life [1].

After conducting evaluation and reflection, it is found that in this course, students are less accustomed to produce superior works that are based on conservation, less apply conservation values in campus life; lecturers are less likely to familiarize students in responding to the meaning of conservation by getting used to excellent activities such as high responsibility, high tolerance, fast response, and high discipline. In the material of dance appreciation, lecturers give less practice to the students about appreciating the campus environment to be made as the imagination, expression, creativity in making dance movements; lecturers lack the habit of getting students to inspire creating dance work related to conservation.

Dance performances are one part of the educational skill and created to produce dance work that is staged in front of audience. The thing important to be done is to blend conservation into dance performance material. The performances of dance works created by students are packed into conservation theme.[2].

The students are given an activity by making a dance performance planning related to the meaning of conservation. The planning is made through how to develop the seven pillars of conservation that will be the theme in the activity of dance performances. After the theme is chosen, the next step is to direct the students to conduct movement exploration activities by responding and developing a movement in accordance with the concept of conservation. In the next step, students are invited to do creativity activities to enrich the results of 
their work by combining the movement that has been found with the design of the composition of dance.

This is reinforced by the expert who says that the creation of a dance created by a choreographer can produce an idea, the concept of motion that is applied through a beautiful and meaningful movement. The movement produced can be regarded as an aesthetic and symbolic dance. Dance as one branch of arts is the expression of human creative imagination through the symbols of motion [3]. Dance as the expression "language" nonverbally related to human feelings. The freedom of self-expression is as an opening inspiration in entering the stage of creativity to get an idea when the process of dance creation is formed. The forms of dance consist of a series of rhythmic motion associated with space structure (space), weight, time, flow, and effort [4],[5].

The most essential reason for the researcher to conduct a research on conservation in dance performances is that students can get an outstanding learning experience because they are invited to observe and feel directly related to conservation. The learning experiences that are real and supported by the strategy of involving the environment around the conservation campus are believed to be able to motivate students to deepen the creating the works of dance that are characteristic, in the end those experiences can foster a sense of love in the field of dance and campus. Love in the field of dance and campus will be the basic asset in creating and developing academic works that have substantial academic character. The research objectives are as follows: 1) to find the implementation of conservation learning process in dance performance at PGSD UNNES and 2) to present performances of student dance work as conservation studies in dance performances.

\section{METHOD}

The design of thinking in the dance performance lecture with conservation insight can be visualized with the following diagram:

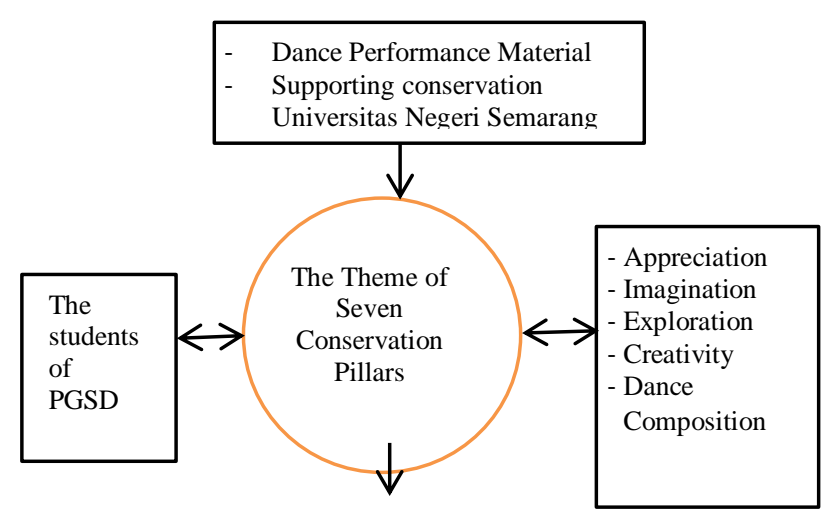

The Performances of

Conservation Dance Works
The subjects of this research are students who take the course of dance education. In this research, the sampling technique used by the researcher was purposive sampling. Purposive sampling is a sample that focuses on selected informants who are rich with cases for in-depth research [6]. The total number of students being sampled was 50 students.

\section{Data Collection Techniques}

a. Documentation analysis: it was used to identify and analyze issues about dance learning faced by PGSD students.

b. Questionnaires were used to: 1) obtain data on the implementation of the dance education lectures conducted by lecturers, 2) to obtain factual data about the interest of students and audiences about dance performances based on conservation in creating superior works and preparing graduates who are excellent, creative, productive, independent, competitive and characterized.

\section{c. Observation}

Observation is the activity of observing something without affecting and simultaneously recording for use as an analysis material. Two things to note, namely: 1) Observing everything about the lecture implementation of dance performances based on conservation,

d. Field Notes Technique

The field notes include notes on research activities during the lecture of dance performances.

\section{Data analysis technique}

The methods used in the process of dance creation were research by practice including appreciation of dance, imagination, exploration, creativity, dance composition, and concept formation. While the data analysis technique used is qualitative analysis with descriptive. Method qualitative data are data expressed in terms of words, sentences, and images. Qualitative technique was conducted through the stage of reducing data, presenting a research procedure that gave descriptive data in the form of written or spoken words of the people and behavior observed. In the data reduction stage, it was conducted by analyzing the overall data, then they were selected to be detailed in each part. Presenting data was done by: presenting the detailed data in the form of tables or graphs, while making a conclusion was done through studying, interpreting, comparing and taking the final conclusion from the data [7]

\section{RESULT}

The Implementation of Conservation Learning Process in Dance Performance:

1. Complying with attitude, knowledge, and skill, the learning process of the conservation and dance knowledge concept was taught in a coherent and complete way. It did not only deepen the dance knowledge but it taught, guided and trained students to be skilled in moving, and creating dance work [5].

2. Carrying conservation studies in dance performances. The dance works with seven conservation pillars: (1). 
conservation of biodiversity, (2). green architecture and internal transportation system, (3). waste management, (4). paper policy, (5). clean energy, (6). conservation, ethics, art, and culture, (7). conservation cadre.

3. Applying superior works. When learning dance, all groups were able to create original dance works with good quality.

4. Implementing contextual learning. Practicing inquiry, modeling, creativity, and evaluation

5. Accustoming the growth of positive habits. Conducting activities by familiarizing good habits. Such as practicing attitudes of responsibility, discipline, obedience, high confidence, courage, tolerance, and respect for other' works.

6. Involving the conservation learning process with the environment around the campus. The process of creating dance works involved the environment around the campus by responding to all the assets that could be made to produce exploration moves. Discovering the idea of motion and finally it could be expressed into a rhythmic, beautiful, and meaningful motion.

7. Growing active participation, enjoy, and enthusiasm. Growing active participation, movement individually and in groups. Applying a form that was enjoy, happy, relaxed, and serious.

8. Growing appreciation by getting used to give critics, suggestions, appreciation of others' work, and create the movement work.

9. Growing imagination and inspiration. From the stimulus given, it was continued on the activities of imagination. Growing inspiration could be done by finding theme ideas, varied movements, and varied compositions.

10. Doing Exploration, Creativity, and Composition of dance. Growing exploration activities by developing themes into varied motion, it could be variations in the count and even the form of motion. Growing creativity could be done by finding varied moves, properties, and dance costumes. The dance composition consisted of a floor pattern, with varying levels, face direction, and canon or sequential motion [8]. Dance composition formed varied like a circular shape, straight line, and the combination of straight lines with a circle. The results of the floor pattern can be seen clearly as follows:

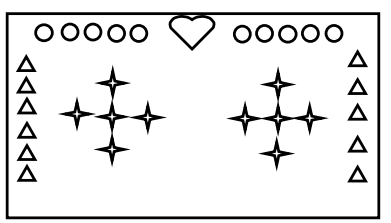

Picture 1. The floor pattern of straight line

The Implementation

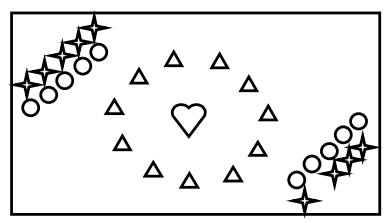

Picture 2. The floor pattern of the combination of
Process in Dance Performance is obtained as the following table 1.

Table 1: Dance Performance

\begin{tabular}{|c|c|c|c|c|c|c|c|c|}
\hline No & Indikator & P1 & $\mathrm{P}_{2}$ & P3 & P4 & Total Skor & $\begin{array}{l}\text { Precentage } \\
(\%)\end{array}$ & Kntenia \\
\hline 1 & $\begin{array}{l}\text { Compliance with attitude, } \\
\text { knowledge, and skill. }\end{array}$ & 5 & 5 & 5 & 5 & 20 & 100 & Very good \\
\hline 2 & $\begin{array}{l}\text { Canying conservation } \\
\text { studies in dance } \\
\text { performances }\end{array}$ & 5 & 5 & 5 & 5 & 20 & 100 & Very good \\
\hline 3 & Applying superior works & 4 & 4 & 4 & 5 & 17 & 85 & Very good \\
\hline 4 & $\begin{array}{l}\text { Implementing contextual } \\
\text { leaming }\end{array}$ & 3 & 4 & 3 & 5 & 15 & 75 & Very good \\
\hline 5 & $\begin{array}{l}\text { Accustoming the growth } \\
\text { of positive habits }\end{array}$ & 3 & 3 & 4 & 5 & 15 & 75 & Very good \\
\hline 6 & $\begin{array}{l}\text { The conservation leaning } \\
\text { process involved the } \\
\text { environment around the } \\
\text { campus }\end{array}$ & 5 & 5 & 5 & 5 & 20 & 100 & Very good \\
\hline 7 & $\begin{array}{l}\text { Growing active } \\
\text { participation, enjoy, and } \\
\text { enthusiasm }\end{array}$ & 5 & 5 & 5 & 5 & 20 & 100 & Very good \\
\hline 8 & Growing appreciation & 4 & 4 & 5 & 5 & 18 & 90 & Very good \\
\hline 9 & $\begin{array}{l}\text { Growing imagination and } \\
\text { inspiration }\end{array}$ & 4 & 4 & 5 & 5 & 18 & 90 & Very good \\
\hline 10 & $\begin{array}{l}\text { Exploration, Creativity, } \\
\text { and Composition of dance }\end{array}$ & 4 & 4 & 5 & 5 & 14 & 70 & good \\
\hline & Precentage $(\%)$ & 84 & 86 & 92 & 100 & 88,5 & 88,5 & Very good \\
\hline & & Good & eery goo & ty gor & Very gooc & 000 & 1000 & \\
\hline
\end{tabular}

The forms of dance performances as the conservation studies in dance work performances.

The performances of dance works produced by students included creation related to the seven pillars of

The titles and synopsis in the works of dance performances included:

1). The Dance of Tri Hita Karana with the theme of green architecture and internal transportation system

The synopsis of this dance: "There were people living in a beautiful village. They always keep the environment clean and safe. But there were some people who were destroying nature in order to fulfill their interests. The good people tried to awaken the bad people about the importance to conserve the environment. But the effort was not successful, nature became damaged". The properties used were flowers, dance fans, ribbons, and batik fabric.

2). The Dance of Gelora Kaderisasi Konservasi with the theme of conservation cadre

The synopsis of the dance: "Sometimes, humans suddenly become thirsty for change, but in fact they only rush to change the way occasionally. Many of them are not aware that their hands have been tied to the trellis of indignity, they just casually walk without any sense of embarrassment. That is our duty to help them remove the binding grate so that the hands can be grasped and we lead to the better." The properties used included: shawl, winnower (picture 3) and mask (picture 4).

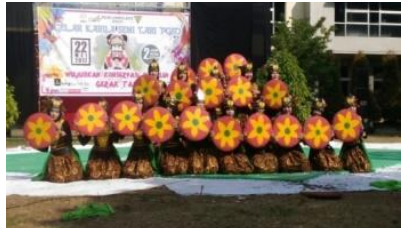

Picture 3

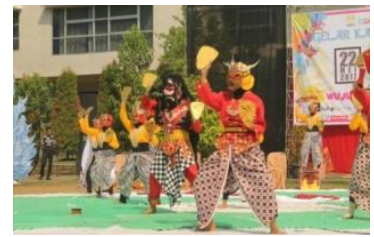

Picture 4 


\section{3). The Dance of Parang Pamukti with the theme conservation, ethics, art, and culture}

The synopsis of the dance: "Batik is the art of painting on the fabric that characterizes the Indonesian nation. Parang batik that implies an advice to someone wearing this batik for not easily giving up and being sturdy as a rock. The word sidomukti describes a hope for a life which is full of happiness and prosperity". The properties used were: batik cloth, shawl, and dance fan

4). The Dance of Hutanku with the theme of biodiversity conservation

The synopsis of the dance: "In the inland of Borneo, there was a very beautiful forest which had many beautiful trees and creatures. Until one day, there came some men who claimed themselves more advanced who destroyed the forest. Suddenly the Goddess came to save the forest.." The properties used in this dance were: gun and shawl.

\section{5). The Dance of Mahaba Adhukoro with the theme of clean energy}

The dance synopsis is: "A good environment can be seen from the happiness of its residents who can unite and synergize to keep nature. But in its journey, there are obstacles with the destructive negative power. This power comes to influence people who are unconscious and ignore conservation values. The properties used were: stick, winnower, dance fan, sword, spear, and tree.

\section{CONCLUSION}

The performances of dance works produced by students included creation related to the seven pillars of conservation and the work of dance. The dance performances based on conservation are regarded as successful ones if they contain aesthetic elements of motion power, motion creativity, motion composition, accuracy of accompaniment, feeling the theme, unity in performance, makeup costumes and properties can reinforce the themes and attract attention of audiences.

\section{REFERENCES}

[1] Powers, Richard. "Brief Histories of Social Dance". Social Dance at Stanford. Stanford
University. Retrieved 2015-04-29.Blom, L, A. and Tarin Chaplin, L. The Intimate Act of Choreography. Dance Books. ISBN 0-82295342-0. 1989.

[2] Minton, S, C. Choreography: A Basic Approach Using Improvisation. Human Kinetics ISBN 0-88011-529-7. 1997.

[3] Giguere, Miriam. Social Influences on the Creative Process: An Examination of Children's Creativity and Learning in Dance. International Journal of Education \& the Arts. Volume 12 Special Issue 1.5. ISSN 1529-8094. http://www.ijea.org/v12si1/. 2011.

[5] Martono, Hendro. Koreografi Lingkungan: Menggali Rasa Indonesia. Seminar Nasional Seni Pertunjukan dan Pendidikan Seni. ISBN.978-602-73437-0-2. Hlm 12-21. 2015.

[6] UPT Pengembangan Konservasi UNNES..Tujuh Pilar Konservasi UNNES. 2017.http://konservasi.unnes.ac.id/?page_id=37 8

[7] UPT-Pengembangan Konservasi UNNES. 2016. Education Dance Archipelago an Effort to Raise Identity Nation. ISSN: 2548-4613_Vol.1 Desember2016.7http://aisteel.unimed.ac.id/pro ceeding-aisteel.2016/

[8] Nurharini, Atip.. The Use of Environment as Learning Sources of Arts Appreciation For Primary School. Proceeding International Conference 386-394. ISSN. 2503-5185. 2016. https://publikasiilmiah.ums.ac.id/handle/11617 17240

[9] Ellfeldt, L. A Primer for Choreographers. Waveland Press. ISBN 0-88133-350-6. (1998)

[10] Gose, Rebecca., Grace, Siemietkowsk. A Collaboration in Care: Re-visioning TeacherStudent Dialogue in Dance Education. International Journal of Education \& the Arts. Volume 19 Number 14. https://doi.org/10.18113/P8ijea1914. 2018.

[11] Weiner, E. J. Beyond "doing” cultural studies: Toward a cultural studies of critical pedagody. The review of education, pedagogy, and culture studies Vol. 25. 55-73. 200 